\title{
Penerapan Model Pembelajaran Inkuiri Terbimbing untuk Mereduksi Miskonsepsi pada konsep Gerak Lurus Siswa SMA Kelas X
}

\author{
Nana $^{1^{*}}$ \\ ${ }^{1}$ Program Studi Pendidikan Fisika, Universitas Siliwangi, Tasikmalaya, Indonesia \\ *e-mail korespondensi: nana@unsil.ac.id \\ (masuk: 02-06-2020; revisi: 26-06-2020; diterima: 29-06-2020)
}

\begin{abstract}
Abstrak: Penelitian ini bertujuan untuk mereduksi Miskonsepsi pada konsep Gerak Lurus Siswa SMA kelas X-MIA 4 SMA N Ciamis melalui model pembelajaran Inkuiri Terbimbing. Jenis penelitian ini adalah Penelitian Tindakan Kelas (PTK/Classroom Action Research). PTK ini menggunakan model Kurt Lewin yang terdiri dart empat komponen, yaitu: perencanaan, tindakan, pengamatan, dan refleksi. Hubungan keempat komponen itu dipandang sebagai satu siklus. Data yang dikumpulkan dalam penelitian ini meliputi data informasi tentang keadaan siswa dilihat dari aspek kualitatif dan kuantitatif. Berdasarkan ketercapaian target yang telah ditentukan diawal sebelum siklus, maka hasil tindakan pada siklus I dikatakan masih kurang berhasil. Miskonsepsi siswa setelah tindakan semakin meningkat daripada sebelum tindakan, sedangkan miskonsepsi berkurang akan tetapi siswa yang tidak memahami konsep semakin bertambah. Jika dilihat dari rata-rata ketercapaian hasil pretest dan post-test, miskonsepsi yang dialami siswa berkurang sebesar $17,74 \%$. Hasil ini belum mencapai hasil yang sesuai target yang dibuat yaitu 25\%. Secara keseluruhan siklus II terlaksana dengan baik akan tetapi masih tetap belum mencapai target yang telah ditentukan. Setiap siklus selalu meningkat yaitu pada siklus I miskonsepsi berkurang $17,74 \%$, siklus II berkurang $21,43 \%$ dan Siklus III miskonsepsi berkurang $62,50 \%$. Hal ini membuktikan bahwa model pembelajaran Inkuiri Terbimbing dapat mereduksi miskonsepsi yang terjadi pada siswa.
\end{abstract}

Kata kunci: model pembelajaran inkuiri, miskonsepsi, gerak lurus

\section{PENDAHULUAN}

Miskonsepsi atau salah konsep menunjuk pada suatu konsep yang tidak sesuai dengan pengertian ilmiah atau pengertian yang diterima para pakar dalam bidang tersebut (Suparno, 2005). Miskonsepsi tersebut berkaitan dengan tingkat pemahaman siswa dalam menangkap materi pelajaran berbedabeda. Pemahaman semua unsur yang terdapat dalam fisika membutuhkan suatu proses yang tidak mudah bagi sebagian siswa, Kemampuan menyerap segala fakta, konsep dan teori ilmu pengetahuan hanya dapat dilakukan oleh siswa yang memiliki kemampuan berfikir yang kuat.
Kebanyakan siswa yang kemampuannya dalam bidang fisika lemah akan mengalami miskonsepsi dalam belajar fisika (Suparno, 2005).

Miskonsepsi disebabkan oleh bermacam-macam hal. Secara umum dapat disebabkan oleh siswa sendiri, guru yang mengajar, konteks pembelajaran, cara mengajar dan buku teks. Prakonsepsi siswa sebelum memperoleh pelajaran, lingkungan masyarakat dimana siswa tinggal, teman, pengalaman menangkap pengertian dan minat siswa ikut andil dalam menyebabkan siswa mengalami miskonsepsi (Nana, 2018; Van den Berg, 1991). Ditambah lagi penggunaan metode 
mengajar oleh guru yang tidak sesuai dengan tujuan materi yang diajarkan menyebabkan siswa menerima konsep lain dari yang dimaksud. Guru cenderung menggunakan metode yang kurang melibatkan siswa secara aktif yaitu menggunakan metode ceramah dan siswa hanya mendengarkan. (Maulana,2010)

Pendekatan inkuiri sains menurut pendapat (Gulo W, 2002), adalah sesuatu yang sangat menantang dan melahirkan interaksi antara yang diyakini siswa sebelumnya terhadap suatu bukti baru untuk mencapai pemahaman yang lebih baik, melalui proses dan metode eksplorasi untuk menguji gagasan-gagasan baru. Hal ini merujuk pada pengembangan sikapsikap positif untuk mencari penjelasan dan menghargai pendapat orang lain, terbuka pada gagasan baru, berfikir kritis, jujur, kreatif dan berfikir lateral. Dengan model pembelajaran ini memungkinkan terjadinya pembelajaran yang mengungkap konsepsi siswa, adu argument dan memunculkan konflik kognitif sehingga dapat mengubah konsep siswa yang salah menjadi benar (Pujianto, 2009).

Beberapa penyebab Miskonsepsi menurut (saparini, 2009; Tayubi, 2005) antara lain: (1). Guru yang mengalami miskonsepsi akan menurunkan miskonsepsi kepada siswanya. (2) Ilustrasi dan konsep-konsep yang ditulis tidak jelas pada buku akan dapat menimbulkan miskonsepsi. (3)Pengaruh atau pengalaman lalin yang mirip dengan konsep-konsep baru yang dihadapkan kepadanya, misalkan miskonsepsi yang terjadi pada arus listrik akibat pengalaman seseorang dalam mengamati arus air. (4). Konsep abstrak yang sulit dibayangkan, misalnya siswa sulit memahami bahwa gaya gesekan pada balok atau benda yang didorong dengan gaya yang berangsurangsur makin besar tetapi tetap diam, gaya gesekan yang dialami benda atau balok juga berangsur-angsur makin besar. Penggunaan istilah atau kata pada percakapan sehari-hari yang dapat memberikan makna yang berbeda dengan arti ilmiah yang sebenarnya, misalnya gesekan dalam Fisika lain sekali artinya dengan gesekan yang terjadi antara kelompok-kelompok dimasyarakat Momentum di Fisika lain sekali artinya dengan istilah momentum di kehidupan sehari-hari yang artinya waktu.

Strategi pembelajaran inkuiri merupakan strategi pembelajaran yang banyak dianjurkan karena strategi ini memiliki beberapa keunggulan diantaranya sebagai berikut:

1) Strategi ini merupakan strategi pembelajaran yang menekankan kepada pengembangan aspek kognitif, afektif dan psikomotorik secara seimbang sehingga pembelajaran melalui strategi ini dianggap bermakna.

2) Strategi ini dapat memberikan ruang kepada siswa belajar sesuai dengan gaya belajar mereka.

3) Strategi ini merupakan strategi yang dianggap sesuai dengan perkembangan psikologi belajar modern yang menganggap belajar adalah proses perubahan tingkah laku berkat adanya pengalaman.

4) Keuntungan lain adalah strategi pembelajaran ini dapat melayani kebutuhan siswa yang memiliki kemampuan di atas rata-rata. Artinya siswa yang memiliki kemampuan belajar bagus tidak akan terhambat oleh siswa yang lemah dalam belajar (Roostiyah, 2008; Gulo, 2002; Majid,2013; Syaifudin,2008; Tayubi, 2005).

Dalam mempelajari Fisika siswa telah mempunyai konsep sendiri sebelum mengikuti pelajaran. Konsep-konsep yang mereka miliki dibentuk dari pengalamanpengalaman mereka terhadap peristiwaperistiwa yang terjadi di sekitarnya. Konsep-konsep awal yang dimiliki siswa sebelum menerima pelajaran inilah yang dlsebut prakonsep. Hal ini didukung oleh beberapa pendapat para ahli diantaranya: Van den Berg (1991:10) menyatakan bahwa "Prakonsep adalah konsepsi yang dimiliki siswa sebelum pelajaran walaupun mereka sudah pernah mendapatkan pelajaran formal". 
Filsafat konstruktivisme secara singkat menyatakan bahwa pengetahuan itu dibentuk (dikonstruksi) oleh siswa sendiri dalam kontak dengan lingkungan, tantangan, dan bahan yang dipelajari. Oleh karena siswa sendiri yang mengkontruksi, dapat saja terjadi siswa telah melakukan konstruksi itu sejak awal sebelum mereka mendapatkan pelajaran formal tentang bahan tertentu. Mereka mengonstruksi sendiri hal itu karena pengalaman hidup mereka. Inilah yang disebut prakonsepsi atau konsep awal siswa (Suparno, 2005).

Pengetahuan awal siswa terhadap konsep-konsep fisika menyebabkan siswa mempunyai penafsiran, pendapat terhadap suatu konsep tertentu. Hal inilah yang disebut konsepsi. Sesuai dengan pendapat Van den Berg (1991) yang menyatakan bahwa "Konsepsi adalah tafsiran perorangan dari suatu konsep ilmu". Misal, inti konsep dari proses melihat sebuah benda adalah benda dapat dilihat oleh mata sebab benda tersebut memancarkan cahaya sendiri atau memantulkan cahaya yang berasal dari sumber cahaya yang mengenainya kemudian cahaya tersebut sampai ke mata. Konsep tersebut membuat banyak siswa memiliki konsepsi berbeda, siswa cenderung berpikir bahwa benda dapat dilihat oleh mata karena benda tersebut hanya memantulkan cahaya yang mengenainya sampai ke mata.

Pengetahuan awal yang dibentuk siswa ada yang sesuai dengan pengetahuan para pakar akan tetapi sering kali tidak cocok dengan pengetahuan yang diterima oleh para pakar dan menjadi suatu konsep yang salah atau miskonsepsi. Sebagai contoh siswa telah memiliki banyak pengalaman dengan peristiwa-peristiwa yang berkaitan dengan konsep dinamika partikel, oleh karena itu siswa sudah banyak mengembangkan konsepsi yang belum tentu sama dengan konsepsi fisikawan. Prakonsep yang dimiliki siswa belum tentu benar. Adapun pengertian miskonsepsi menurut para ahli adalah sebagai berikut:

Menurut Alan K, Griffith, Kevin Thomey, Bren Cooke, dan Glen Normore mendeskripsikan miskonsepsi sebagai kesalahan pemahaman yang terjadi selama atau sebagai hasil dari pengajaran yang baru saja diberikan, berkembang dalam waktu yang lama. Jadi, menurut pendapat tersebut miskonsepsi atau kesalahan pemahaman merupakan pertentangan antara konsep yang diterima dengan konsep yang telah dimiliki oleh orang lain atau siswa sebagai peserta didik. (Saparini, 2009:11)

$$
\text { Van Den Berg }
$$

mendefinisikan miskonsepsi sebagai "konsepsi siswa bertentangan dengan konsepsi para fisikawan". Suparno (2005) menyatakan bahwa: "Konsep awal yang tidak sesuai dengan konsep ilmiah itu biasanya disebut miskonsepsi atau salah konsep". Fowler dalam Suparno (2005) "memandang miskonsepsi sebagai pengertian yang tidak akurat akan konsep, penggunaan konsep yang salah, klasifikasi contoh-contoh yang salah, kekacauan konsep-konsep yang berbeda dan hubungan hierarkis konsep-konsep yang tidak benar".

\section{METODE PENELITIAN}

Data yang dikumpulkan dalam penelitian ini meliputi data informasi tentang keadaan siswa dilihat dari aspek kualitatif dan kuantitatif. Data yang dikumpulkan ditujukan untuk mengetahui apakah model pembelajaran yang dikembangkan mampu mengurangi miskonsepsi yang terjadi pada siswa. Aspek kualitatif berupa data hasil observasi, wawancara, dan kajian dokumen atau arsip. Aspek kuantitatif yang dimaksud adalah hasil pre-test dan post-test yang dilaksanakan sebelum dan setelah pelaksanaan tindakan yaitu pembelajaran menggunakan model Inkuiri terbimbing. (Abraham,1994; Arifin, 2012)

Observasi/Pengamatan dilakukan dengan tujuan agar dapat mengetahui proses pembelajaran Fisika menggunakan Model pembelajaran Inkuiri terbimbing. Observasi yang dilakukan adalah observasi sistematik dimana telah dirancang bentuk instrumen pengamatan yang akan dilakukan dalam proses pembelajaran beserta aspek-aspek yang akan diteliti. 
Penyusunan aspek-aspek ini dibuat dalam bentuk lembar observasi. (Auster, 2006; Moleong, 2011; Rosdakarya, 2010)

Observasi/pengamatan terhadap siswa difokuskan pada aktivitas siswa dalam proses pembelajaran. Sementara observasi/pengamatan guru diarahkan pada kegiatan guru dalam pembelajaran fisika dengan model inkuiri terbimbing (Nonoh, 2012; Sarwiji, 2009; Suharsimi, 2010)

\section{HASIL DAN PEMBAHASAN}

Berdasarkan hasil wawancara pra siklus terhadap guru Fisika SMAN 1 Ciamis, disampaikan oleh beliau bahwa pembelajaran yang dilakukan masih sering menggunakan metode ceramah dan tanya jawab, sesekali melakukan demonstrasi dan menggunakan power point untuk media pembelajaran. Metode diskusi dan eksperimen masih jarang dilakukan karena pertimbangan materi dan alokasi waktu pembelajaran yang ditetapkan. Waktu dalam mempersiapkan pembelajaran kurang, disamping itu tuntutan materi yang harus diajarkan di kelas X sangat banyak.

Berdasarkan beberapa hal yang telah diungkapkan di atas terdapat beberapa permasalahan yang muncul yaitu 1) proses pembelajaran yang terjadi berjalan satu arah artinya guru yang lebih aktif dalam proses pembelajaran, siswa mendengarkan ceramah guru dari awal hingga akhir pembelajaran, guru lebih mendominasi kegiatan pembelajaran di kelas, siswa kurang terlibat aktif dalam pembelajaran, 2) Imbas dari hal tersebut siswa hanya memperoleh suapan-suapan konsep tanpa pernah memahami konsep tersebut sehingga siswa pasif dalam menggali konsep yang diajarkan, 3) Beberapa siswa kurang tertarik dengan pembelajaran yang dilakukan. Siswa menginginkan pembelajaran yang membuat mereka lebih aktif dan lebih menyenangkan.

Permasalahan di atas mengakibatkan hasil ulangan siswa pada konsep Gerak Lurus tidak maksimal. Sebanyak 33 siswa mengikuti pembelajaran di kelas tersebut, ada 11 siswa tidak tuntas. Jika dipersentasekan kira-kira ada 33\% siswa yang tidak tuntas.

Setelah melakukan observasi tersebut, peneliti dan guru menyusun suatu tindakan yang mengarah untuk mengurangi miskonsepsi. Tindakan tersebut adalah melalui penerapan model Inkuiri Terbimbing pada pembelajaran Fisika pada konsep Gerak Lurus. Diharapkan model ini dapat mengurangi miskonsepsi yang terjadi pada siswa pada konsep Gerak Lurus(Sardinian,2007)

Pada tahap perencanaan, peneliti dan guru secara kolaboratif menyusun Rencana Pelaksanaan Pembelajaran. Melalui media dan LKS serta modul yang telah disusun, peneliti dan guru memberikan masukan terutama pada LKS. Model yang digunakan adalah inkuiri terbimbing maka peneliti dan guru menyusun RPP dan LKS dengan mempertimbangkan kejelasan bahasa dan penulisan serta cakupan materi yang diberikan sehingga dengan LKS yang telah disusun, siswa mampu menemukan suatu konsep.

Materi yang dikaji pada siklus I adalah Gerak Lurus Beraturan. Penjabaran materi serta LKS yang digunakan dapat dilihat pada RPP (Rencana Pelaksanaan Pembelajaran) yang telah dibuat pada lampiran 5 dan lampiran 1. Peneliti dan guru merencanakan menggunakan model pembelajaran Inkuiri Terbimbing dengan metode diskusi dan eksperimen. Media yang digunakan berupa denah dari beberapa lokasi yang digunakan untuk menjelaskan materi tentang jarak, perpindahan, kecepatan, kelajuan, kecepatan rata-rata dan kelajuan ratarata. (Nana,2014)

Setelah RPP, LKS dan media selesai disusun, dilakuan konsultasi kepada ahli. Berdasarkan analisis yang telah dilakukan oleh para ahli diperoleh kesimpulan bahwa RPP, LKS dan media yang digunakan cukup baik. Adapun beberapa komentar dan saran yang diberikan oleh ahli dalam penyusunan instrumen adalah penyusunan LKS harus dibuat berurutan dan sesuai alur yang runtut sehingga 
mudah dipahami oleh siswa dan diharapkan dengan LKS tersebut dapat mengarahkan siswa menemukan konsep sendiri. Perumusan soal tes diagnostik juga harus mampu menjawab indikator yang dibuat. Selain itu pembimbing juga menyarankan untuk membuat sintak pembelajaran untuk mempermudah guru dalam melaksanakan pembelajaran sesuai dengan alur yang ada di RPP. (Susilowati,2012)

Di siklus yang pertama ini, siswa direncanakan untuk mengerjakan soal tes diagnostik miskonsepsi untuk mengetahui miskonsepsi siswa. Tes ini dilakukan di awal pertemuan (postest) sebelum pembelajaran dimulai dan setelah pembelajarn befakhir (pretest). Adapun soal yang digunakan pada saat tes sebelum dan setelah pembelajaran adalah sama dengan tujuan agar dapat mengukur peningkatan pemahaman siswa setelah diberikna tindakan dengan model inkuiri terbimbing. (Wardhani,2007).

Instrumen lain yang digunakan adalah lembar observasi pelaksanaan pembelajaran dan draft pertanyaan untuk kegiatan wawancara. Jumlah observer sebanyak 2 orang yang masing-masing mengamati perilaku guru saat memberikan pembelajaran dan perilaku siswa saat pembelajaran berlangsung.
Target ketercapaian yang dibuat secara kolaboratif oleh peneliti dan guru didasarkan pada kemampuan dan keadaan siswa. Adapun target yang disepakati yaitu setelah dilaksanakan pembelajaran dengan menggunakan model Inkuiri Terbimbing, miskonsepsi yang terjadi pada siswa terhadap konsep Gerak Lurus berkurang $25 \%$.

Pelaksanaaan pembelajaran diawali dengan membuka kelas oleh guru dengan memberikan salam kemudian mengabsen kehadiran siswa. Siswa yang hadir pada pertemuan siklus I sebanyak 31 siswa dari 33 siswa. Dua orang siswa tidak masuk karena sakit. Sebelum memulai pembelajaran guru memberikan soal pretest kepada siswa dengan alokasi waktu 8 menit. Setelah itu guru membagikan LKS dan Media pembelajaran yang berupa denah dan dua koin sebagai penanda sebuah posisi kepada masing-masing kelompok. Guru lalu memberikan penjelasan singkat mengenai materi dan kegiatan yang akan dilakukan pada pembelajaran tersebut kepada siswa.

Adapun hasil pretest dan post-test siswa pada siklus I untuk indikator yang telah dibuat dalam penelitian ini dapat dilihat pada Tabel 1 .

Tabel l. Hasil Pretest dan Post-test Siswa Siklus I

\begin{tabular}{|c|c|c|c|c|c|c|c|c|}
\hline \multirow{2}{*}{ No } & \multirow{2}{*}{ Indikator } & \multirow{2}{*}{$\begin{array}{l}\text { No. } \\
\text { Soal }\end{array}$} & \multicolumn{2}{|c|}{ Memahami } & \multicolumn{2}{|c|}{ Miskonsepsi } & \multicolumn{2}{|c|}{ Tidak Memahami } \\
\hline & & & Pre & Post & Pre & Post & Pre & Post \\
\hline 1 & $\begin{array}{l}\text { Mengidentifikasi dan } \\
\text { membedakan antara } \\
\text { jarak dan } \\
\text { perpindahan }\end{array}$ & 1 & 35,48 & 77,41 & 54,83 & 19,35 & 9,67 & 9,67 \\
\hline 2 & $\begin{array}{l}\text { Membedakan } \\
\text { kecepatan rata-rata } \\
\text { dan kelajuan rata-rata } \\
\text { Memahami }\end{array}$ & 2 & 6,45 & 9,67 & 35,48 & 48,38 & 58,06 & 41,93 \\
\hline 3 & $\begin{array}{l}\text { karakteristik alat } \\
\text { ukur kelajuan dan } \\
\text { kecepatan }\end{array}$ & 3 & 12,90 & 48,38 & 80,64 & 51,61 & 6,45 & 0 \\
\hline 4 & $\begin{array}{l}\text { Mengemukakan } \\
\text { perbedaan kecepatan } \\
\text { dan kedudukan }\end{array}$ & 4 & 29,03 & 29,03 & 32,25 & 12,90 & 38,70 & 58,06 \\
\hline & $\begin{array}{l}\text { g-rata hasil tiap } \\
\text { gori }\end{array}$ & 5 & 20,97 & 41,12 & 50,80 & 33,06 & 28,22 & 27,42 \\
\hline
\end{tabular}


Berdasarkan kondisi siswa yang telah diamati, sebelum tindakan siklus 1 dimulai ditentukan target yang hendak dicapai yaitu miskonsepsi berkurang $25 \%$. Berdasarkan ketercapaian target yang telah ditentukan diawal sebelum siklus, maka hasil tindakan pada siklus I dikatakan masih kurang berhasil. Hal ini dapat dilihat dari tabel 4.1 dimana pada soal no 2 miskonsepsi siswa setelah tindakan semakin meningkat daripada sebelum tindakan, sedangkan pada soal no. 4 miskonsepsi berkurang akan tetapi siswa yang tidak memahami konsep semakin bertambah. Jika dilihat dari rata-rata ketercapaian hasil pretest dan post-test, miskonsepsi yang dialami siswa berkurang sebesar $17,74 \%$. Hasil ini belum mencapai hasil yang sesuai target yang dibuat yaitu $25 \%$.

Berdasarkan hasil pembelajaran pada siklus I, masih perlu dilakukan perbaikan yaitu dengan melanjutkan ke tindakan II supaya ketercapaian dapat lebih ditingkatkan. Selain mengupayakan untuk meningkatkan pemahaman siswa juga diupayakan untuk meningkatkan motivasi belajar siswa agar lebih tinggi dari target yang sudah dicapai di siklus I.

Motivasi belajar siswa pada siklus I masih kurang, hal ini dapat dilihat dari hasil observasi pada saat pembelajaran berlangsung siswa masih banyak yang melakukan aktivitas belajar seperti melamun, Berdiskusi diluar konteks, mengerjakan pekerjaan rumah mata pelajaran lain dan sikap duduk yang tidak siap menerima pelajaran.

Setelah pembelajaran siklus I selesai dilaksanakan, peneliti juga melakukan wawancara terhadap guru untuk meminta apresiasi, tanggapan dan evaluasi dari keberlangsungan pembelajaran dari siklus I. Guru menyatakan bahwa secara keseluruhan pembelajaran berjalan dengan baik dari segi keseriusan dan ketertarikan siswa mengikuti pembelajaran akan tetapi masih ada yang perlu diperbaiki seperti pemilihan bahasa dalam LKS supaya lebih disederhanakan lagi karena disela-sela pembelajaran masih banyak siswa yang bertanya tentang kejelasan bahasa LKS.

Guru dan peneliti menyusun rencana tindakan lanjut untuk mencapai target yang lebih baik pada siklus II sebagai berikut:

a. Perlu adanya alokasi waktu untuk mengkondisikan siswa dalam kelompok agar siap menerima pelajaran.

b. Mengingatkan siswa untuk mendiskusikan hasil percobaannya dengan teman satu kelompok dan bertanya apabila ada kesulitan.

c. Perlunya bimbingan mengenai prosedur melakukan percobaan agar siswa benar-benar mengerti apa yang dilakukan.

Perlu adanya perbaikan soal tes diagnostik agar sesuai dengan materi yang diajarkan secara keseluruhan dari tahap siklus I, siklus II, dan siklus III. Perubahan hasil ketercapaian secara keseluruhan dari tahap siklus I, siklus II, dan siklus III dapat digambarkan dalam diagram garis pada gambar 4,11.

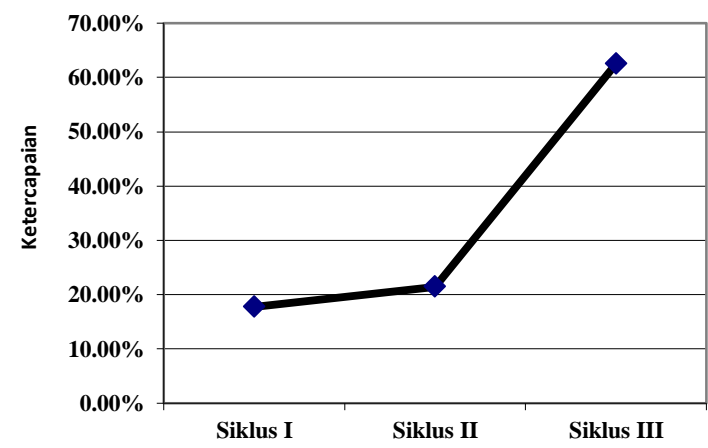

Gambar 1. Ketercapaian siklus I, Siklus II, Siklus III

Berdasarkan Gambar 1 menunjukkan bahwa berkurangnya miskonsepsi pada setiap siklus selalu meningkat yaitu pada siklus I miskonsepsi berkurang $17,74 \%$, siklus II berkurang $21,43 \%$ dan Siklus III miskonsepsi berkurang $62,50 \%$. Hal ini membuktlkan bahwa model pembelajaran Inkuiri Terbimbing dapat mereduksi miskonsepsi yang terjadi pada siswa. Majid (2013:223) menyatakan "Strategi pembelajaran inkuiri merupakan rangkaian kegiatan pembelajaran yang menekankan pada proses berpikir kritis dan analitis untuk 
mencari dan menemukan sendiri jawaban dari suatu masalah yang dipertanyakan". Kegiatan tersebut memancing siswa untuk mengerti konsep yang benar sehingga mengurangi miskonsepsi, Kegiatan pembelajaran tersebut harus dibimbing oleh guru. Penelitian dapat dikatakan berhasil karena indikator yang diukur telah mencapai target yang ditetapkan.

Dengan melihat data-data di atas yang telah disesuaikan dengan teori maka telah ditemukan model mengajar yang tepat untuk materi Gerak Lurus pada kelas X-MIA 4. Model tersebut adalah model Inkuiri Terbimbing dengan metode diskusi kelompok dan eksperimen dengan bantuan media yang sederhana

\section{SIMPULAN}

Telah dilaksanakan Penelitian Tindakan Kelas untuk mereduksi miskonsepsi terkait konsep gerak lurus pada siswa SMA Kelas X. Perlakuan yang diberikan adalah menggunakan model pembelajaran Inkuiri terbimbing. Berdasarkan hasil penelitian, maka dapat disimpulkan bahwa Penerapan model pembelajaran Inkuiri Terbimbing dapat mereduksi 62,50\% miskonsepsi siswa pada materi Gerak Lurus kelas X-MIA 4 SMA N Ciamis.

\section{Referensi}

Abraham, M.R., Vickie M.W., \& Susan L.W. (1994). A Cross-Age Study of the Understanding of Five Chemistry Concepts. Journal of Research in Science Teaching, 31 (2), 147-165.

Arifin, Zainal. (2012). Penelitian Pendidikan. Bandung: PT Remaja Rosdakarya

Auster, E. \& Wylie, K. (2006). Creating Active Learning in the Classroom: A Systematic Approach. Journal of Management Education

Gulo,W. (2002). Strategi Belajar Mengajar. Jakarta : Gramedia Widiasarana.

$\begin{array}{cr}\text { Majid, } \quad \text { Abdul. (2013) } & \text { Strategi } \\ \text { Pembelajaran. } & \text { Bandung: } \\ \text { PT.Remaja Rosdakarya } & \end{array}$

Maulana. (2010). Usaha Mengurangi Miskonsepsi Fisika Melalui Pembelajaran Dengan Pendekatan
Konflik Kognitif. Jurnal Pendidikan Fisika Indonesia.

Moleong, L. J. (2011). Metode Penelitian Kualitatif. Bandung: PT Remaja

Rosdakarya Mulyadi. (2010). Diklat Penelitian Tindakan Kelas. Semarang: Lembaga Penjaminan Mutu Pendidifcan Jawa Tengah

Nana. (2014). Pengembangan Pembelajaran POE2WE dalam Pembelajaran Fisika SMA. (Surakarta: Disertasi UNS).

Nana. (2014). The Effectivenes of Scientific Approach Through Predict, Observe, Explain, Elaborate, Write, and Evaluate (POE2WE). The Social Sciencer 11 (6), 1028-1034.

Nana, Sajidan, Akhyar, M., \& Rochsantiningsih, D. (2014). Pengembangan Pembelajaran Fisika SMA Melalui Elaboration Write and Evaluation (EWE) dalam Kurikulum 2013. Seminar Nasional Pendidikan Sains. [Online]. Tersedia:

https://jurnal.fkip.uns.ac.id/index.p $\mathrm{hp} /$ snps/article/view/4944 [30 November 2019].

Nana, Sajidan, Akhyar, M., \& Rochsantiningsih, D. (2014). The Development Of Predict, Observe, Explain, Elaborate, Write, and Evaluate (POE2WE) Learning Model in Physics Learning At Senior Secondary School. Journal of Education and Practice. 5 (19): 59.

Nana, (2018). Penggunaan Pendekatan Konflik Kognitif untuk remidiasi miskonsepsi konsep suhu dan kalor. Seminar Nasional Pendidikan Sains ( SNPS). Surakarta FKIP UNS.

Nonoh Siti Aminah. (2012). Dasar-dasar Penelitian Pembelajaran dan Penelitian Tindakan Kelas. Surakarta : UNS Press

Paul Suparno. (2005). Miskonsepsi \& Perubahan Konsep Pensisikan Fisika. Jakarta: PT. Grasindo

Pujianto, Agus, Nurjannah dan I wayan Darmadi. Analisis Miskonsepsi Siswa Pada Konsep Kinematika 
Gerak Lurus. Jurnal Pendidikan Fisika, Tadulako.

Roestiyah, N. K. (2008). Strategi Belajar Mengajar. Jakarta : Rineka Cipta

Saparini. (2009). Identiflkasi Miskonsepsi pada Konsep Optik Geometri. Skripsi Tidak Dipublikasikan. Universitas Sebelas Maret, Surakarta.

Sarwiji Suwandi. (2009). Penelitian Tindakan Kelas (PTK) dan Penulisan Karya Tulis Ilmiah. Surakarta: Panitia Sertifikasi Guru Rayon 13 FKIP UNS

Suharsimi, Suhardjono, \& Supardi. (2010). Penelitian Tindakan Kelas. Jakarta : PT. Bumi Aksara

Sardinian. (2007). Interaksi \& Motivasi Belajar Mengajar. Jakarta : PT Raja Grafindo Persada

Susilowati, A.D. (2012). Penyusunan Tes Diagnostik Fisika SMA Kelas X di SMA 2 Sukoharjo. Skripsi Tidak Dipublikasikan. Universitas Sebelas Maret, Surakarta.

Syaifudin, Ahmad. (2008). Implementasi Model Pembelajaran Penemuan Terbimbing dalcan Matematika Untuk Mengurangi Miskonsepsi Geometri Siswa Kelas VIII SMP N 3 Bulukamba Brebes Tahun Ajaran . 2007/2008. Perpustakaan Digital UIN Sunan Kalijaga Yogyakarta

Tayubi, Yuyu R. (2005). Identiftkasi Miskonsepsi pada Konsep-Konsep Fisika Menggunakan Certainty of Response Index (CRI). Mimbar Pendidikan. Universitas Pendidikan Indonesia

Van Den Berg, Euwe (Ed). (1991). Miskonsepsi Fisika dan Remediasi. Salatiga: Universitas Kristen Satya Wacana.

Wardhani. dkk. (2007). Penelitian Tindakan Kelas. Jakarta: Universitas Terbuka 